\title{
Determination of shelf-life using accelerated shelf-life testing (ASLT) method and characterization of the flavour components of freeze-dried durian (Durio zibethinus) products
}

\author{
${ }^{1,2^{*}}$ Darniadi, S., ${ }^{3}$ Handoko, D.D., ${ }^{1}$ Sunarmani, S. and ${ }^{1}$ Widowati, S. \\ ${ }^{1}$ Indonesia Center for Agricultural Postharvest Research and Development (ICAPRD), Bogor, Indonesia \\ ${ }^{2}$ Department of Food Technology, University of Pasundan, Bandung, Indonesia \\ ${ }^{3}$ Laboratory of Flavor Analysis, Indonesia Center for Rice Research, Subang, Indonesia
}

\begin{abstract}
Article history:
Received: 7 December 2020

Received in revised form: 2 March 2021

Accepted: 29 June 2021

Available Online: 12 July 2021
\end{abstract}

Keywords:

Shelf-life,

ASLT method,

Flavour,

Durian,

Freeze-drying

DOI:

https://doi.org/10.26656/fr.2017.5(S2).006

\begin{abstract}
Durian is a unique tropical fruit that has a strong smell and distinctive taste. It is a seasonal fruit and has a few days shelf-life. Freeze drying is known for preserving foods while maintaining its original shape and provide excellent rehydrated products. This study aimed to determine the shelf-life of freeze-dried (FD) durian products using the accelerated shelf-life testing (ASLT) method and to assess the flavour changes in fresh and freeze-dried durian products. The parameters used to determine shelf-life were moisture content and $\mathrm{L}^{*} \mathrm{a}^{*} \mathrm{~b}^{*}$ colour values of FD durian products for 28 days of storage at 30,40 , and $50^{\circ} \mathrm{C}$. Flavour analysis using Solid Phase Microextraction (SPME) and Gas Chromatography-Mass Spectrometry (GCMS) was carried out on fresh durian pulp, FD durian for $30 \mathrm{hrs}$, and FD durian for $36 \mathrm{hrs}$. The estimation of shelf-life of FD durian products at storage temperatures of 25 and $30^{\circ} \mathrm{C}$, respectively, were based on the following parameters: (1) moisture content: 41 and 37 days, (2) $L^{*}$ (brightness): 467 and 311 days, (3) a* (redness): 144 and 171 days, and (4) b*(yellowness): 43 and 46 days. A total of twenty-four volatile compounds contributed to the flavour of fresh durian fruit and five of them had concentrations of more than $10 \mathrm{ppm}$. The losses percentage of these five volatile compounds were in a range of $78-95 \%$ (FD durian for $30 \mathrm{hrs}$ ) and a range of 0 $100 \%$ (FD durian for $36 \mathrm{hrs}$ ). Freeze-drying technique on durian was able to extend shelflife and preserve flavour compounds.
\end{abstract}

\section{Introduction}

Durian (Durio zibethinus) family Bombacacea is a seasonal tropical fruit from Southeast Asia (Malaysia, Thailand, Philippines and Indonesia (Ho and Bhat, 2015). Ripe durian fruit has a distinctive aroma, and taste, therefore it is called the 'king fruit' (Ho and Bhat, 2015). Durian fruit requires some form of handling process before consumption. For example, separating the edible (fleshy) part from the non-edible portion, separating the adherent waxy layer. Durian also requires separating the pulp from the skin, which is similar to jackfruit. Some studies reported that exotic fruits such as durian contain bioactive components/phytochemicals (Gorinstein et al., 2011; Ho and Bhat, 2015). Durian fruit is also rich in micro and macronutrients, contains essential minerals and vitamins $\mathrm{A}, \mathrm{C}$, and $\mathrm{E}$ (Ho and Bhat, 2015; Charoenkiatkul et al., 2016).

As a prevalent fruit in Southeast Asia, durian is commonly consumed in the form of fresh pulp. The market of durian fruit is very limited in the sense that it depends on the fruit harvest season and the constraints on marketing fresh fruit are also very limited due to the durian's shelf-life of 2-5 days at ambient temperature (Chin et al., 2008). Therefore, the processing of fresh durian fruit into dry whole fruit is more necessary because drying of the fruit yields several advantages including reduced transportation costs, practical consumption, and product stability against microorganisms and adverse biochemical reactions (Chin et al., 2010).

Above all types of drying methods for agricultural products that have been engineered up to date, freezedrying is a drying method that is widely applied in the food industry where several drying principles are used (Chin et al., 2008). Drying agricultural products through freeze-drying techniques uses the ice sublimation mechanism under vacuum conditions. Freeze drying can slow down the deterioration of the product by 
minimization of loss of flavour and aroma, maximization of nutrient retention because of the low temperature involved in the process (Ratti, 2013).

The freeze-drying method for durian fruit into powder/durian powder has been carried out by several researchers (Chin et al., 2008; Chin et al., 2010) but the application of freeze-drying to produce dried durian pulp has not been carried out by other researchers. An important parameter that needs to be determined in the production of freeze-drying durian is the possibility of reducing volatile durian flavour compounds due to the effect of drying (Chin et al., 2010). The difference in the aroma characteristics of several varieties of durian is a key factor in consumer acceptance (Belgis et al., 2017).

The quality of freeze-dried durian is also governed by its shelf-life. Shelf-life can be determined by observing the product during storage until changes occur that are no longer acceptable to consumers (Asiah et al., 2018). Determination of shelf-life using the ASLT (Accelerated Shelf-life Testing) method for pineapple, papaya, cempedak, and shallot products has been studied in other studies (Arif, 2016; Setyadjit et al., 2017). To the best of our knowledge, the determination of the shelflife of freeze-dried durian products has not been performed by other researchers.

In the light of the above, the objective of this study was to determine the shelf-life of freeze-dried durian using the ASLT method and to assess changes in the flavour of freeze-drying durian products due to the drying process applied.

\section{Materials and methods}

\subsection{Chemical and standards}

The chemicals used are $\mathrm{NaCl}$ (Merck, Germany), Alkenes (C8-C28) and 1,4-dichlorobenzene (Aldrich, Germany) as standard internal solutions. Standard flavour solutions (maltol, ethyl-2-butyrate, diethyl disulphide, hexanal, acetyl-6-pyridine, and 2-methylbutanol) were obtained from PT. Mane Flavour and Fragrance, Jakarta, Indonesia

\subsection{Preparation of frozen durian}

Durian was selected from local market in Cianjur, West Java, and the pulp was then separated from the seeds for crushing using a food processor (Russel Hobs, $\mathrm{UK}$ ) at $300 \mathrm{rpm}$ for $5 \mathrm{mins}$ into durian pulp. Durian pulp was removed into a plastic food container until the thickness level of $2 \mathrm{~cm}$ and was formed into a $3 \mathrm{~cm}^{2}$ square. The durian pulp was then placed into a commercial freezer (GEA, Indonesia) at $-40^{\circ} \mathrm{C}$ for 24 hrs.

\subsection{Freeze-drying condition}

The freeze-drying process followed the methods of Ceballos et al. (2012) and Darniadi et al. (2019) with slight modifications. The frozen durian pulp samples were transferred to a stainless-steel pan, then placed into a Freeze-Dryer (Buchi Lyovapor L-200, Switzerland) at $55^{\circ} \mathrm{C}$, vacuum pressure $0.04 \mathrm{~m}$ bar for 30 and $36 \mathrm{hrs}$. The dried durian samples were removed from the freezedryer and packed in aluminum foil for analysis.

\subsection{Moisture content}

A HB-120 Halogen Moisture Analyzer (Mettler Toledo, UK) set at $105^{\circ} \mathrm{C}$ was used to measure the moisture content of FD durian. A total of $1 \mathrm{~g}$ of freezedrying durian powder sample was placed on the sample pan, then the lid of the moisture analyzer was lowered until it was tightly closed. The drying time ranged from 2 to 3 mins for each sample.

\subsection{Colour measurement}

Colour measurement followed the method by Faridah et al. (2013). The colour value of FD durian was measured using a Chromameter (Konica Minolta) which produced the Hunter L* (brightness), a* (redness), and $\mathrm{b}^{*}$ (yellowness) values. Where $\mathrm{L}^{*}$ : Value $(+)=$ light colour, $(-)=$ dark colour; $\mathrm{a}^{*}$ : Value $(+)=$ red, $(-)=$ green and $b^{*}$ : Value $(+)=$ yellow, $(-)=$ blue

\subsection{Accelerated shelf-life testing of FD durian}

ASLT method was done according to Arif (2016). FD durian for 36 hrs was chosen for accelerated shelflife testing. The samples packed in aluminium foil were placed in the storage incubator at 30,40 , and $50^{\circ} \mathrm{C}$. A set of sampling was done every 7 days, from day 0 to 28 . The physicochemical properties data obtained were plotted against time, then the linear regression equation was calculated for the three acceleration temperatures, using the equation $\mathrm{Y}=\mathrm{a}+\mathrm{bx}$, where $\mathrm{Y}=$ Physical properties of FD durian, $\mathrm{x}=$ storage time (days), $\mathrm{b}$ or $\mathrm{k}=$ rate of change. The value of $b$ is also called the slope, which is the rate of deterioration. Zero order is determined by relating between the physical value (At) and the storage time $(\mathrm{t})$, while the first order is calculated by relating $\ln$ value (ln At) with storage time $(\mathrm{t})$. The degradation of the zero-order is expressed as the following equation:

At $-\mathrm{A}_{0}=-\mathrm{kt}$

Where At $=$ Amount $\mathrm{A}$ at time $\mathrm{t}, \mathrm{A}_{0}=$ The initial number $\mathrm{A}, \mathrm{k}=$ rate of deterioration and $\mathrm{t}=$ storage time

The equation for quality degradation with time first order is formulated by the equation: 
$\ln \mathrm{At}-\ln \mathrm{A}_{0}=-\mathrm{kt}$

After obtaining the slope, intercept, and $\mathrm{R}^{2}$ (zero order and first order), then the equation that has the largest $\mathrm{R}^{2}$ was chosen for calculating the product shelflife using the Arrhenius Model:

$\ln \mathrm{k}=\ln \mathrm{k}_{0}-(\mathrm{Ea} / \mathrm{R})(1 / \mathrm{T})$

Where $\ln \mathrm{k}_{0}=$ intercept, $\mathrm{Ea} / \mathrm{R}=$ slope, $\mathrm{Ea}=$ activation energy, $\mathrm{R}=$ ideal gas constant $=1.986 \mathrm{cal} / \mathrm{mol}{ }^{\circ} \mathrm{K}$ and $\mathrm{T}$ $=$ temperature $\left({ }^{\circ} \mathrm{K}\right)$

The relationship between the $\ln \mathrm{k}$ and $(1 / \mathrm{T})$ was formed as a graph. The $\mathrm{K}_{0}$ and the Ea were obtained from the graph. The key parameters were determined from the smallest activation energy (Ea). The shelf-life of the product was estimated by calculating the difference between the initial rate $\left(\mathrm{A}_{0}\right)$ and the value the rate at a certain time (At) using the following equation:

$$
\begin{array}{ll}
\text { ts }=\left[\ln \left(\mathrm{N}_{\mathrm{o}}-\mathrm{Nt}\right)\right] / \mathrm{kT} & \text { for first order } \\
\text { ts }=\left(\mathrm{N}_{0}-\mathrm{Nt}\right) / \mathrm{kT} & \text { for for zero order }
\end{array}
$$

Where ts $=$ storage time, $\mathrm{N}_{0}=$ the initial rate at $\mathrm{t}_{0}, \mathrm{Nt}=$ the rate after storage time $\mathrm{t}$ (critical limit) and $\mathrm{KT}=\mathrm{k}$ at storage temperature $\mathrm{T}$

\subsection{Flavour analysis}

\subsubsection{Solid-phase micro extraction (SPME)}

SPME was carried out according to Zhang et al. (2007). A total of $50 \mathrm{~g}$ of fresh durian pulp and FD durian were homogenized with $100 \mathrm{~mL}$ of $\mathrm{NaCl}$ solution $(0.08 \mathrm{~g} / \mathrm{mL})$ and stirred for $1 \mathrm{~min}$. Following this, 12.5 $\mathrm{mL}$ homogenates were put into a $22 \mathrm{~mL}$ vial with the top cap number 2713 and put into the vial the magnetic stirrer $(\mathrm{p} \times \mathrm{d}=10 \mathrm{~mm} \times 3 \mathrm{~mm})$. Next, $0.5 \mu \mathrm{L}$ of internal standard (IS) 1,4-dichlorobenzene $0.01 \%(\mathrm{w} / \mathrm{v})$ was spiked into the sample and the vial was tightly closed. SPME fiber syringe (divinylbenzene-carboxenpolydimethylsiloxane $85 \mu \mathrm{m}$, Supelco Inc., PA, USA) was manually inserted to the vial headspace at $30^{\circ} \mathrm{C}$ for 30 minutes and injected into GC-MS.

\subsubsection{Gas chromatography-mass spectrometry (GC-MS)}

GC-MS analysis was conducted using GC-MS Agilent 7890A-5975C based on the method of Belgis et al., (2017). Chromatographic separation was performed using an HP-INNOWAX column $(30 \mathrm{~m} \times 0.25 \mathrm{~mm}$ i.d. $0.25 \mu \mathrm{m}$ film thickness) with the following equipment conditions: helium as carrier gas at a constant flow of 1.0 $\mathrm{mL} / \mathrm{min}, \mathrm{P}: 60 \mathrm{kPa}$; electron ionization voltage $70 \mathrm{eV}$; injector temperature $250^{\circ} \mathrm{C}$; oven initial temperature to $40^{\circ} \mathrm{C}$ and increased to $80^{\circ} \mathrm{C}$ in increments of $3^{\circ} \mathrm{C} / \mathrm{min}$., hold for $1 \mathrm{~min}$, increased to $130^{\circ} \mathrm{C}$ in increments of $2^{\circ} \mathrm{C} /$ min, hold for $2 \mathrm{mins}$, increased to $240^{\circ} \mathrm{C}$ in increments of $6^{\circ} \mathrm{C} / \mathrm{min}$, mass scanning to charge ratio $33-400 \mathrm{~m} / \mathrm{z}$. The identification of volatile compounds was based on comparison of the mass spectra with those shown in the NIST 2.0 database and confirmed by reference publications. The linear retention index (LRI) was calculated using the linear retention data of the alkane solution (C8-C28) in n-hexane. The relative amount of volatile compounds was calculated by comparing the peak area and peak IS area, where $5 \mu \mathrm{L}$ Is with $50 \mathrm{~g}$ of sample. The data were analysed as the mean value of two replications.

\section{Results and discussion}

\subsection{The shelf-life of FD durian based on moisture} content

The moisture content of FD durian products during storage (28 days) is shown in Figure 1. The initial moisture content of FD durian products was $9.9 \%$ and increased during storage at 30,40 , and $50^{\circ} \mathrm{C}$. From Figure 1, it can be seen that the moisture content of FD durian ranged from $9.9-13.9 \%$. The highest increasing in moisture content was shown at of $30{ }^{\circ} \mathrm{C}$, followed by at 40 and $50{ }^{\circ} \mathrm{C}$, respectively.

The $\mathrm{R}^{2}$ of the linear equations for orders 0 and 1 was shown in Table 1 . The $\mathrm{R}^{2}$ of zero order was higher than first order. Therefore, the calculation of shelf-life based on the moisture content was done for zero order. The moisture content slopes of zero order were 0.136 ; 0.087 ; and 0.093 , stored at 30,40 , and $50^{\circ} \mathrm{C}$, respectively (Table 2). By plotting the inverse value of absolute temperature (1/T) against k (slope), the Arrhenius graph was obtained. The Arrhenius equation obtained was $\ln \mathrm{k}$ $=-8.353+19021 / \mathrm{T}$, where the $\ln \mathrm{k}_{0}=-8.353,(\mathrm{Ea} / \mathrm{R})=$ 1902.

Table $1 . \mathrm{R}^{2}$ (determination) of linear regression for zero order and first order order obtained from different storage temperatures and parameters

\begin{tabular}{lccc}
\hline \multirow{2}{*}{ Parameter } & $\begin{array}{c}\text { Storage } \\
\text { temperature }\left({ }^{\circ} \mathrm{C}\right)\end{array}$ & \multicolumn{2}{c}{$\mathrm{R}^{2}$ (Determination) } \\
\cline { 3 - 4 } Moisture content & 30 & Zero order & First order \\
& 40 & 0.97 & 0.95 \\
& 50 & 0.99 & 0.98 \\
\hline \multirow{2}{*}{ L $^{*}$ (Brightness) } & 30 & 0.87 & 0.94 \\
& 40 & 0.83 & 0.86 \\
& 50 & 0.93 & 0.95 \\
\hline \multirow{2}{*}{$\mathrm{a}^{*}$ (Redness) } & 30 & 0.77 & 0.76 \\
& 40 & 0.93 & 0.93 \\
\hline \multirow{3}{*}{$\mathrm{b}^{*}$ (Yellowness) } & 50 & 0.99 & 0.99 \\
\hline
\end{tabular}

The shelf-life of FD durian was calculated employing the input storage temperature of $5^{\circ} \mathrm{C}=278^{\circ} \mathrm{K}$, 

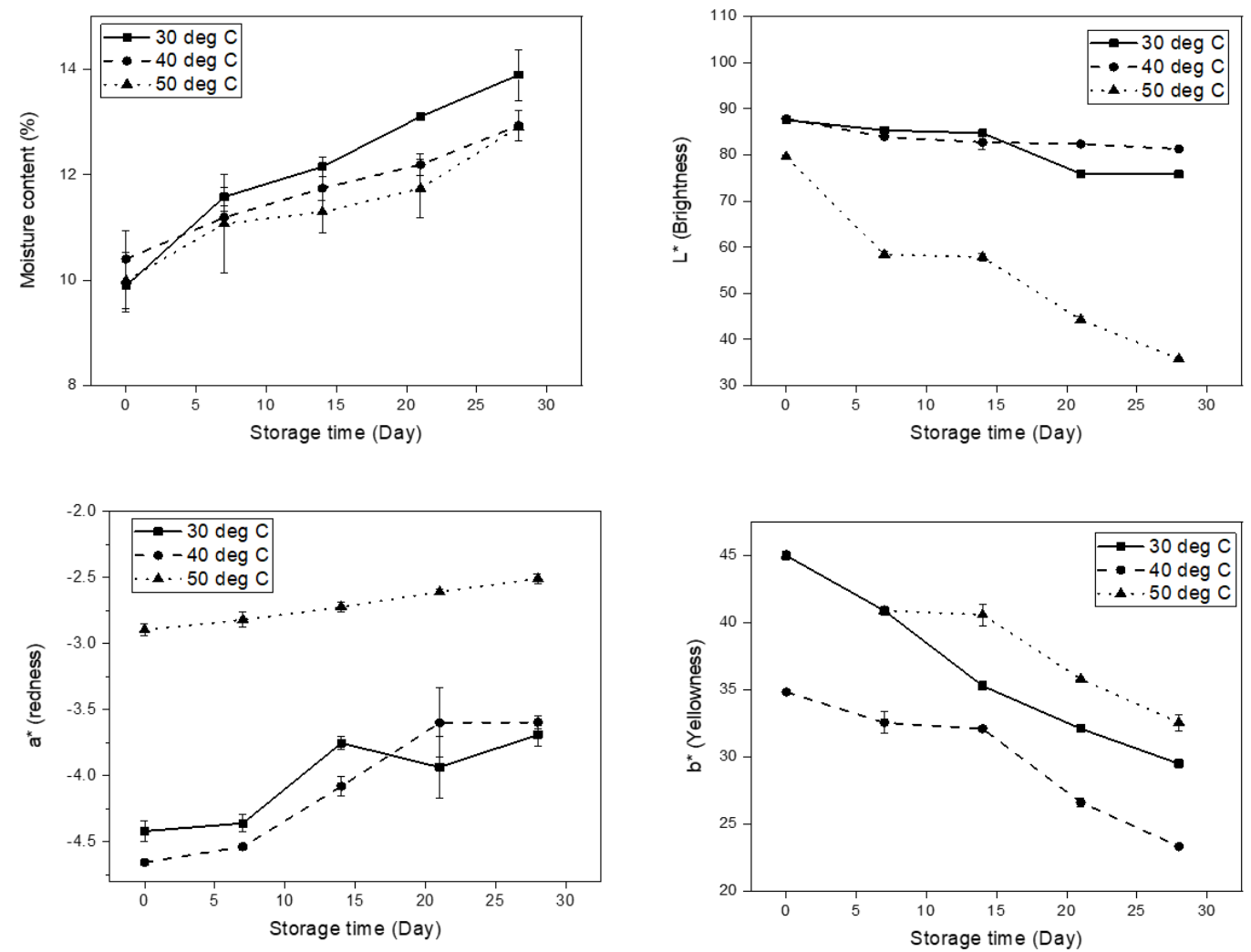

Figure 1. Moisture content and $\mathrm{L}^{*} \mathrm{a} * \mathrm{~b} *$ of freeze-dried durian stored at 30,40 , and $50^{\circ} \mathrm{C}$

Table 2. Slope and $\mathrm{ln} \mathrm{k}$ of linear regression of zero order and first order obtained from different storage temperatures and parameters

\begin{tabular}{|c|c|c|c|c|c|c|c|c|c|}
\hline \multirow{2}{*}{ Parameter } & \multicolumn{2}{|c|}{ Temperature } & \multirow{2}{*}{$1 / \mathrm{T}$} & \multicolumn{3}{|c|}{ Zero order } & \multicolumn{3}{|c|}{ First order } \\
\hline & ${ }^{\circ} \mathrm{C}$ & ${ }^{\circ} \mathrm{K}$ & & Slope & $\mathrm{k}$ & $\ln \mathrm{k}$ & Slope & $\mathrm{k}$ & $\ln \mathrm{k}$ \\
\hline \multirow{3}{*}{ Moisture content } & 30 & 303 & 0.00330 & 0.136 & 0.136 & -1.955 & 0.012 & 0.012 & -4.468 \\
\hline & 40 & 313 & 0.00319 & 0.087 & 0.087 & -2.447 & 0.007 & 0.007 & -4.900 \\
\hline & 50 & 323 & 0.00310 & 0.093 & 0.093 & -2.378 & 0.008 & 0.008 & -4.810 \\
\hline \multirow{3}{*}{ L* (Brightness) } & 30 & 303 & 0.00330 & -0.470 & 0.470 & -0.756 & -0.006 & 0.006 & -5.153 \\
\hline & 40 & 313 & 0.00319 & -0.209 & 0.209 & -1.567 & -0.003 & 0.003 & -6.003 \\
\hline & 50 & 323 & 0.00310 & -1.455 & 1.455 & 0.375 & -0.027 & 0.027 & -3.618 \\
\hline \multirow{3}{*}{$\mathrm{a}^{*}$ (Redness) } & 30 & 303 & 0.00330 & 0.027 & 0.027 & -3.616 & -0.006 & 0.006 & -5.020 \\
\hline & 40 & 313 & 0.00319 & 0.044 & 0.044 & -3.131 & -0.011 & 0.011 & -4.538 \\
\hline & 50 & 323 & 0.00310 & 0.014 & 0.014 & -4.625 & -0.005 & 0.005 & -5.253 \\
\hline \multirow{3}{*}{ b* (Yellowness) } & 30 & 303 & 0.00330 & -0.568 & 0.568 & -0.566 & -0.016 & 0.016 & -4.166 \\
\hline & 40 & 313 & 0.00319 & -0.413 & 0.413 & -0.884 & -0.014 & 0.014 & -4.246 \\
\hline & 50 & 323 & 0.00310 & -0.428 & 0.428 & -0.849 & -0.011 & 0.011 & -4.498 \\
\hline
\end{tabular}

then $\ln \mathrm{k}=-1.5112$ or $\mathrm{k}=0.22063$ was obtained, durian during 28 days of storage. They were in a range meaning that the increase in moisture content was 0.22063 units per day. Therefore, the total quality units until expiry date were calculated by subtracting the initial moisture content (9.89) from the critical limit moisture content (15), resulting in 5.2 units. The estimated shelf-life of FD durian products were 37 and 41 days, at 25 and $30^{\circ} \mathrm{C}$ respectively (Table 3 ).

\subsection{The shelf-life of FD durian based on L* (brightness)}

Figure 1 shows the change in brightness of FD 34.74 to 87.82 . The sharp decrease of $\mathrm{L}^{*}$ occurred for samples stored at $50^{\circ} \mathrm{C}$, i.e., from 79.6 to 35.7. Different conditions appeared for samples stored at 30 and $40^{\circ} \mathrm{C}$, the decrease was relatively moderate, from 87.5 to 75.8 , and from 87.8 to 81.3 , respectively. The conditions described above, indicate the phenomenon of nonenzymatic browning or the Maillard reaction, where heat react with carbohydrates and proteins, and had changed the colour to brown (dark colour).

The $\mathrm{R}^{2}$ of orders 0 and 1 was shown in Table 1 . The $\mathrm{R}^{2}$ of first order was higher than zero order. Therefore, 
Table 3. Shelf-life of freeze-dried durian calculated from moisture content and colour values

\begin{tabular}{ccccc}
\hline \multirow{2}{*}{$\begin{array}{c}\text { Prediction Temperature } \\
\left({ }^{\circ} \mathrm{C}\right)\end{array}$} & \multicolumn{4}{c}{ Shelf-life based on properties (days) } \\
\cline { 2 - 5 } & Moisture content & L*/Brightness & $\mathrm{a}^{*} /$ redness & b*/yellowness \\
\hline-5 & 66.9 & 7365.0 & 45.2 & 25.4 \\
5 & 61.1 & 2749.5 & 68.4 & 30.7 \\
10 & 55.7 & 1724.4 & 83.3 & 33.5 \\
15 & 50.7 & 1099.1 & 100.7 & 36.6 \\
20 & 45.9 & 711.5 & 121.0 & 39.7 \\
25 & 41.4 & 467.3 & 144.4 & 43.1 \\
30 & 37.3 & 311.2 & 171.4 & 46.6 \\
35 & 33.5 & 210.0 & 202.3 & 50.2 \\
40 & 29.9 & 143.5 & 237.5 & 54.0 \\
45 & 26.6 & 99.2 & 277.4 & 57.9 \\
50 & 23.6 & 69.4 & 322.4 & 62.0 \\
55 & 18.3 & 49.1 & 373.1 & 66.3 \\
\hline
\end{tabular}

the calculation of shelf-life based for the $\mathrm{L}^{*}$ value was performed for the first order. The $\mathrm{L}^{*}$ slopes of the first order were $-0.006 ;-0.003$; and -0.027 , stored at 30,40 , and $50^{\circ} \mathrm{C}$, respectively (Table 2). By plotting the absolute temperature inverse value $(1 / \mathrm{T})$ against $\mathrm{k}$, the Arrhenius graph was obtained. The Arrhenius equation obtained was $\ln \mathrm{k}=16.57+53881 / \mathrm{T}$, where the value of $\ln \mathrm{k}_{0}=16.57,(\mathrm{Ea} / \mathrm{R})=5388$.

The shelf-life of was calculated through the input storage temperature of $5^{\circ} \mathrm{C}=278^{\circ} \mathrm{K}$, then $\ln \mathrm{k}=-2.8113$ or $\mathrm{k}=0.060$ was generated, meaning that the decrease in $\mathrm{L}^{*}$ value was 0.060 units per day. Therefore, the total quality units until expiration were calculated by subtracting the initial $\mathrm{L}^{*}$, which was 87 , from the critical limit value of 30 , resulting in 57 units. The estimated shelf-life of FD durian products was 467 and 311 days, at 25 and $30{ }^{\circ} \mathrm{C}$, respectively (Table 3 ).

\subsection{The shelf-life of FD durian based on a* (redness)}

Figure 1 shows the change of redness of FD durian during 28 days of storage. The a* of FD durian ranges from -4.66 to. -2.51 which were greenness. It can be seen that during 28 days of storage, the $\mathrm{a}^{*}$ value of FD durian was increase. The $\mathrm{a}^{*}$ of FD durian stored at $50^{\circ} \mathrm{C}$ was the highest value compared to those stored at 30 and $40^{\circ} \mathrm{C}$.

The $\mathrm{R}^{2}$ of orders 0 and 1 was shown in Table 1 . The $\mathrm{R}^{2}$ of zero order is higher than the first order. Therefore, the calculation of shelf-life based on the $\mathrm{a}^{*}$ was carried out for zero order. The $\mathrm{a}^{*}$ slopes of the zero order were $0.027 ; 0.044$; and 0.014 , stored at 30,40 , and $50^{\circ} \mathrm{C}$, respectively (Table 2). By plotting the absolute temperature inverse value $(1 / \mathrm{T})$ against $\mathrm{k}$, the Arrhenius graph was obtained. The Arrhenius equation obtained was $\ln \mathrm{k}=-13.56+30931 / \mathrm{T}$, where the value of $\ln \mathrm{k}_{0}=$ $-13.56,(\mathrm{Ea} / \mathrm{R})=3093$.

The shelf-life of FD durian was calculated through the input storage temperature of $5^{\circ} \mathrm{C}=278^{\circ} \mathrm{K}$, then $\ln \mathrm{k}=$ $-2,434$ or $\mathrm{k}=0.087$ was obtained, meaning an increase of the a* was 0.087 units per day. Therefore, the total quality units to expiry date were calculated by subtracting the initial $\mathrm{a}^{*}$, which was -4.66 , from the critical limit value of 2 , resulting in 6.66 units. The estimated shelf-life of FD durian based on the $\mathrm{a}^{*}$ were 144 and 171 days, stored at 25 and $30^{\circ} \mathrm{C}$, respectively (Table 3).

\subsection{The shelf-life of FD durian based on $b^{*}$ (yellowness)}

The yellowness value of FD durian during 28 days of storage is shown in Figure 1. The $b^{*}$ of FD durian was positive, which was yellow (the colour of fresh durian pulp). The yellowness durian of FD during storage ranged from 23.3 - 45, with the initial $b^{*}$ value of 45 . During storage, the $b^{*}$ was decrease and the lowest level occurred in the samples stored at $40{ }^{\circ} \mathrm{C}$, i.e., 23.3.

The $\mathrm{R}^{2}$ of orders 0 and 1 was shown in Table 1 . The $\mathrm{R}^{2}$ of zero order is higher than first order. Therefore, the calculation of shelf-life based on the $b^{*}$ is carried out in zero order. The $b^{*}$ slope of the zero order were 0.568 ; 0,413 ; and -0.42 , stored at 30,40 , and $50{ }^{\circ} \mathrm{C}$, respectively (Table 2). By plotting the absolute temperature inverse value $(1 / T)$ against $k$, the Arrhenius graph was obtained. The Arrhenius equation obtained was $\ln \mathrm{k}=-5,262+$ $14061 / \mathrm{T}$, where the value of $\ln \mathrm{k}_{0}=-5,262,(\mathrm{Ea} / \mathrm{R})=$ 1406.

The shelf-life of FD durian was calculated by employing the input storage temperature of $5^{\circ} \mathrm{C}=278^{\circ} \mathrm{K}$, then $\ln \mathrm{k}=-0.204$ or $\mathrm{k}=0.815$ was obtained, meaning that the decrease of $b^{*}$ was 0.815 units per day. Therefore, the total quality units to expiry date can be calculated by subtracting the initial $b^{*}$, which was 45 , from the critical limit value of 20 , resulting in 25 units. The estimated shelf-life of FD durian based on the $b^{*}$ were 43 and 46 days, stored at 25 and $30^{\circ} \mathrm{C}$, respectively 
(Table 3)

\subsection{Freeze-dried (FD) durian flavour properties}

The edible portion of the durian fruit is reported to have a unique and strong aroma, associated with esters and volatile sulfur compounds (diethyl disulphide and propanethiol, ethyl 2-methylbutanoate). From the fresh durian pulp, FD durian $30 \mathrm{hrs}$, and FD durian $36 \mathrm{hrs}$ were identified as 24,17 and 18 volatile compounds, respectively (Table 4 ). The most volatile compounds were sulfur (12), followed by alcohols (5), acids (5), esters (4), terpenes (1), ketones (1) and aldehydes (1). Fresh durian was relatively high in diethyl disulfide, limonene, ethyl-1-methylethyl disulfide and diethyl

Table 4. Identification of volatile compounds from fresh and freeze-dried (FD) durian pulp using SPME coupled to GC-MS

\begin{tabular}{|c|c|c|c|c|c|c|c|c|c|}
\hline \multirow[b]{2}{*}{ No } & \multirow{2}{*}{$\begin{array}{c}\mathrm{RT} \\
\text { (minute) }\end{array}$} & \multirow[b]{2}{*}{ Compounds } & \multirow[b]{2}{*}{ Group } & \multirow{2}{*}{$\begin{array}{c}\text { LRI } \\
\text { Experiment }\end{array}$} & \multirow{2}{*}{$\begin{array}{c}\text { LRI } \\
\text { Reference }\end{array}$} & \multicolumn{3}{|c|}{ Volatile amount (ppm) } & \multirow[b]{2}{*}{ Aroma } \\
\hline & & & & & & Fresh pulp & $\begin{array}{c}\text { FD durian } \\
30 \mathrm{hrs}\end{array}$ & $\begin{array}{l}\text { FD durian } \\
36 \mathrm{hrs}\end{array}$ & \\
\hline 1 & 2.002 & Ethanethiol $^{\mathrm{B}}$ & sulfur 1 & & & 9.343 & 3.532 & 14.620 & \\
\hline 2 & 2.276 & Dimethyl sulfide ${ }^{B}$ & sulfur 2 & & & 6.014 & 2.177 & 8.091 & $\begin{array}{l}\text { cabbage, sulfur, } \\
\text { gasoline (12) }\end{array}$ \\
\hline 3 & 2.484 & Ethyl acetate $^{B}$ & acid 1 & & & 6.215 & 5.148 & 25.200 & sweet, fruity (8) \\
\hline 4 & 2.656 & Ethanol $^{\mathrm{B}}$ & alcohol 1 & & & 10.318 & 2.306 & 16.371 & sweet (13) \\
\hline 5 & 3.085 & $\begin{array}{l}\text { Ethyl-2- } \\
\text { methylbutanoate }^{\mathrm{B}}\end{array}$ & ester 1 & & & 3.804 & 1.606 & 6.976 & \\
\hline 6 & 3.562 & Methyl ethyl disulfide ${ }^{\mathrm{A}}$ & sulfur 3 & 1235 & & 4.199 & 0.000 & 0.000 & \\
\hline 7 & 3.756 & Limonene $^{\mathrm{A}}$ & terpen & 1291 & 1192(1) & 32.887 & 1.760 & 12.711 & $\begin{array}{l}\text { ethereal, citrus-like } \\
\text { (14) }\end{array}$ \\
\hline 8 & 3.776 & Diethyl disulfide $^{B}$ & sulfur 4 & 1297 & $1217(2)$ & 36.755 & 2.013 & 19.238 & sulfury, roasty (2) \\
\hline 9 & 4.036 & Acetoin ${ }^{\mathrm{A}}$ & ketone & 1378 & $1272(3)$ & 0.000 & 2.398 & 14.774 & butterscotch (3) \\
\hline 10 & 4.089 & $\begin{array}{l}\text { Ethyl-1-methylethyl } \\
\text { disulfide }^{B}\end{array}$ & sulfur 5 & 1395 & & 17.478 & 1.074 & 6.046 & \\
\hline 11 & 4.179 & Hexanol $^{\mathrm{A}}$ & alcohol 2 & 1425 & $1360(4)$ & 1.238 & 0.000 & 0.000 & green, floral (4) \\
\hline 12 & 4.326 & Dipropyl disulfide ${ }^{\mathrm{A}}$ & sulfur 6 & 1475 & $1370(5)$ & 1.313 & 0.000 & 0.000 & \\
\hline 13 & 4.345 & Nonanal $^{\mathrm{A}}$ & aldehid & 1482 & $1385(4)$ & 0.000 & 0.000 & trace & soapy (4) \\
\hline 14 & 4.433 & Ethyl octanoate ${ }^{\mathrm{A}}$ & ester 2 & 1513 & $1458(6)$ & 0.438 & 0.000 & 0.000 & $\begin{array}{l}\text { floral, fruity, musty } \\
\text { (6) }\end{array}$ \\
\hline 15 & 4.458 & Acetic acid ${ }^{\mathrm{A}}$ & acid 2 & 1522 & $1427(7)$ & 3.526 & 83.819 & 35.988 & vinegar (7) \\
\hline 16 & 4.69 & $\begin{array}{l}\text { Ethyl-3- } \\
\text { hydroxybutyrate }^{B}\end{array}$ & ester 3 & 1608 & & 0.576 & 0.234 & 0.000 & \\
\hline 17 & 4.704 & Propanoic acid & acid 3 & 1613 & $1523(7)$ & 0.936 & 0.000 & 0.000 & Soy (7) \\
\hline 18 & 4.719 & $* 2,3$-butanediol ${ }^{\mathrm{A}}$ & alcohol 3 & 1619 & $1538(6)$ & 0.000 & 6.455 & 27.526 & floral, fruity (6) \\
\hline 19 & 4.755 & Diethyl trisulfide ${ }^{\mathrm{A}}$ & sulfur 7 & 1633 & & 12.963 & 0.000 & 0.000 & \\
\hline 20 & 4.803 & $* 2,3-$ Butanediol $^{\mathrm{A}}$ & alcohol 4 & 1652 & $1538(6)$ & 0.000 & 0.809 & 32.561 & floral, fruity (6) \\
\hline 21 & 5.041 & 2-Methylbutanoic acid ${ }^{\mathrm{A}}$ & ester 4 & 1747 & $1670(8)$ & 8.486 & 7.573 & 32.338 & \\
\hline 22 & 5.082 & $\begin{array}{l}\text { 3,5-Dimethyl-1,2,4- } \\
\text { trithiolane }\end{array}$ & sulfur 8 & 1764 & $1602(9)$ & 6.290 & 0.000 & 0.000 & \\
\hline 23 & 5.166 & Dipropyl trisulfide ${ }^{\mathrm{A}}$ & sulfur 9 & 1799 & $1658(5)$ & 0.663 & 0.000 & 0.000 & \\
\hline 24 & 5.272 & $\begin{array}{l}* * 3 \text {-Ethyl-5-methyl- } \\
\text { 1,2,4- trithiolane }\end{array}$ & sulfur 10 & 1842 & & 0.859 & 0.000 & 0.000 & \\
\hline 25 & 5.283 & $\begin{array}{l}\text { Bis [1-(methylthio)ethyl }] \\
\text {-disulfide }{ }^{B}\end{array}$ & sulfur 11 & 1847 & & 1.114 & 0.000 & 0.000 & \\
\hline 26 & 5.307 & $\begin{array}{l}* * 3 \text {-Ethyl-5-methyl- } \\
1,2,4 \text { - trithiolane }\end{array}$ & sulfur 12 & 1856 & & 0.488 & 0.000 & 0.000 & \\
\hline 27 & 5.481 & Hexanoic acid ${ }^{\mathrm{A}}$ & acid 4 & 1926 & $1863(10)$ & 1.804 & 3.047 & 14.601 & cheese (10) \\
\hline 28 & 5.724 & Phenylethyl alcohol $^{\mathrm{A}}$ & alcohol 5 & 2021 & $1910(11)$ & 0.000 & 0.619 & 1.363 & \\
\hline 29 & 6.069 & Octanoic acid ${ }^{\mathrm{A}}$ & acid 5 & 2140 & $2083(10)$ & 0.649 & 1.116 & 4.124 & cheese (10) \\
\hline
\end{tabular}

All data are the means of two replicates; *2,3-Butanediol and **3-Ethyl-5-methyl-1,2,4- trithiolane has two isomers or stereoisomers; A: identified by mass spectrum and confirmed by retention index reported in literature, i.e., (1) Umano and Shibamoto (1987), (2) Selli et al. (2006), (3) Lee and Noble (2003), (4) Schieberle and Grosch (1987), (5) Takahashi and Shibamoto (2008), (6) Miranda-Lopez et al. (1992), (7) Lee and Noble (2003), (8) Dregus and Engel (2003), (9) Chung et al. (2004), (10) Ferreira et al. (2001), (11) Dregus and Engel (2003), (12) Peterson and Reineccius (2003), (13) Chung, Eiserich and Shibamoto (1993), (14) Schieberle and Grosch (1988); B: identified by mass spectrum 
trisulfide, while FD durian 36 hrs contained relatively high acetic acid, two isomers of 2,3 butanediol, 2 methylbutanoic acid, diethyl disulfide, ethanol, ethanethiol, acetoin and limonene. Compared to the volatile profile of fresh durian, the volatile profile of FD durian $30 \mathrm{hrs}$ was more similar to that of FD durian 36 hrs, but with a lower content of volatile compounds except acetic acid. Among all samples, FD durian $30 \mathrm{hrs}$ contained the most acetic acid compounds. Voon et al., (2007) reported that from durian pulp had been identified 22 esters, 14 sulfur compounds, 7 alcohols, 3 aldehydes and 1 ketone. Furthermore, the main sulfur compounds in durian pulp were diethyl disulphide, ethyl-n-propyl disulphide, diethyl trisulphide and ethanethiol, while the main ester compounds were ethyl propanoate, ethyl-2methyl butanoate, or propyl-2-methylbutanoate.

The freeze-drying process caused the loss of 11 volatile compounds (methyl ethyl disulfide, hexanol, dipropyl disulfide, ethyl octanoate, propanoic acid, diethyl trisulfide, 3,5-dimethyl-1,2,4-trithiolane, dipropyl trisulfide, two 3-ethyl-5-methyl-1,2,4-trithiolane isomers, bis [1- (methylthio) ethyl] -disulfide) and the formation of four new compounds (acetoin, two 2,3butanediol isomers, and phenyl ethyl alcohol) in durian pulp. Chin et al., (2008) reported that the freeze-drying process in durian pulp caused the loss of ethyl thioacetate, propyl butanoate, propyl 2-methylbutanoate and propyl 3-methylbutanoate.

Similar to the freeze-drying process, at $4^{\circ} \mathrm{C}$ of minimally processed durian pulp, most of the ester compounds were lost after 14 days of storage. This result was related to the decline in fruity aroma intensity detected by the panelists during storage. The total durian sulfur content remained unchanged after 42 days of storage, although the sulfur notes perceived by panelists decreased significantly at the end of storage (Voon et al., 2007).

Weenen et al. (1996) reported that two potent odourants in Indonesian durian pulp, e.g., sulfur compounds 3,5-dimethyl-1,2,4-trithiolane, and nonsulfur ethyl compounds 2-methylbutanoate. They also reported that the potent odorant compounds in Monthong durian pulp were ethyl (2S) -2-methylbutanoate, ethanethiol, 1- (ethylsulfanyl) ethane-1-thiol, methanethiol, ethane-1,1dithiol, ethyl 2- methylpropanoate. Furthermore, based on aroma simulations and omission tests, durian aroma, in general, can be formed from a mixture of two compounds, e.g., ethyl (2S) -2-methylbutanoate and 1(ethylsulfanyl) ethane-1-thiol at certain concentrations.

Table 5 shows the amount of representative volatile components in ppm in the samples of fresh and freezedried examined using GC-MS. Diethyl disulfide was the most abundant volatile among the determined analytes with $36.75 \mathrm{ppm}$ in fresh durian pulp. Chin et al. (2008) reported that the amount of Diethyl disulphide from fresh and freeze-dried durian (Variety D24) were $40.85 \mu \mathrm{g} / \mathrm{g}$ and $1.15 \mu \mathrm{g} / \mathrm{g}$, respectively. Freeze-drying caused major reduction of major aroma volatile that ranged from 78$100 \%$ (FD durian $30 \mathrm{hrs}$ ) and $0-100 \%$ (FD durian 36 hrs). The reduction of aroma volatile in freeze-dried durian 36 hrs was lower than other freeze-dried durians in a previous study conducted by Chin et al. (2008), i.e. $72-97 \%$. This result may be due to the drying time, where this study employed longer drying time (36 hrs) compared to a previous study (12 hrs). Furthermore, volatile compounds were influenced by the ice sublimation stage in freeze-drying (Krokida and Philippopoulos, 2006).

\section{Conclusion}

Product of dried durian had been succefully obtained by using laboratory-scale freeze-dryer with two different drying times i.e., 30 and $36 \mathrm{hrs}$. The shelf-life of FD durian at 25 and $30^{\circ} \mathrm{C}$ were based on the following parameters: (1) moisture content 41 and 37 days, (2) L*/ brightness 467 and 311 days, (3) a*/redness: 144 and 171

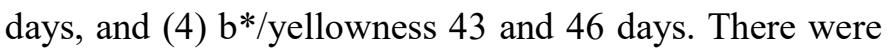
24 volatile compounds that contribute to the flavour of fresh durian pulp and five of them had concentrations of more than $10 \mathrm{ppm}$. The losses percentage of these five volatile compounds were in a range of $78-95 \%$ (FD durian for $30 \mathrm{hrs}$ ) and a range of $0-100 \%$ (FD durian for $36 \mathrm{hrs})$.

\section{Conflict of interest}

The authors declare no conflict of interest.

Table 5. Concentration of target analytes from fresh and freeze-dried (FD) durian (ppm) determined by SPME coupled to GCMS

\begin{tabular}{|c|c|c|c|c|c|}
\hline \multirow{2}{*}{ Volatile compounds } & \multicolumn{3}{|c|}{ Volatile amount (ppm) } & \multicolumn{2}{|c|}{ Volatile Loses ( $\%)$} \\
\hline & Fresh pulp & FD durian $30 \mathrm{hrs}$ & FD durian 36 hrs & FD durian 30 hrs & FD durian 36 hrs \\
\hline Ethanol & 10.31 & 2.30 & 16.37 & 78.00 & 0.00 \\
\hline Limonene & 32.88 & 1.75 & 12.71 & 95.00 & 61.40 \\
\hline Diethyl disufide & 36.75 & 2.01 & 19.23 & 94.60 & 47.70 \\
\hline Ethyl 1-methyethyl disulfide & 17.47 & 1.07 & 6.04 & 93.80 & 64.40 \\
\hline Diethyl trisulfide & 12.96 & 0.00 & 0.00 & 100.00 & 100.00 \\
\hline
\end{tabular}




\section{Acknowledgment}

The authors would like to express their gratitude to the Indonesia Agency for Agricultural Research and Development (IAARD), Ministry of Agriculture for funding this study.

\section{References}

Arif, A.B. (2016). Accelerated Shelf Life Test (ASLT) Method with Arrhenius Approach for Shelf Life Estimation of Pineapple, Papaya and Cempedak Juices. Informatika Pertanian, 25(2), 189-198.

Asiah, N., Cempaka, L. and David, W. (2018). Practical Guideline: Estimating the Shelf-life of Food Products. Jakarta: Penerbitan Universitas Bakrie.

Belgis, M., Wijaya, C.H., Apriyantono, A., Kusbiantoro, B. and Yuliana, N.D. (2017). Volatiles and aroma characterization of several lai (Durio kutejensis) and durian (Durio zibethinus) cultivars grown in Indonesia. Scientia Horticulturae, 220, 291-298. https://doi.org/10.1016/j.scienta.2017.03.041

Ceballos, A.M., Giraldo, G.I. and Orrego, C.E. (2012). Effect of freezing rate on quality parameters of freeze dried soursop fruit pulp. Journal of Food Engineering, 111(2), 360-365. https:// doi.org/10.1016/j.jfoodeng.2012.02.010

Charoenkiatkul, S., Thiyajai, P. and Judprasong, K. (2016). Nutrients and bioactive compounds in popular and indigenous durian (Durio zibethinus murr.). Food Chemistry, 193, 181-186. https:// doi.org/10.1016/j.foodchem.2015.02.107

Chin, S.T., Hamid Nazimah, S.A., Quek, S.Y., Che Man, Y. Bin, Rahman, R.A. and Hashim, D.M. (2010). Effect of thermal processing and storage condition on the flavour stability of spray-dried durian powder. LWT - Food Science and Technology, 43(6), 856861. https://doi.org/10.1016/j.lwt.2010.01.001

Chin, S.T., Nazimah, S.A.H., Quek, S.Y., Che Man, Y., Abdul Rahman, R. and Mat Hashim, D. (2008). Changes of volatiles' attribute in durian pulp during freeze- and spray-drying process. LWT - Food Science and Technology, 41(10), 1899-1905. https:// doi.org/10.1016/j.lwt.2008.01.014

Chung, T.Y., Eiserich, J.P. and Shibamoto, T. (1993). Volatile compounds isolated from edible Korean chamchwi (Aster scaber Thunb). Journal of Agricultural and Food Chemistry, 41(10), 16931697. https://doi.org/10.1021/jf00034a033

Darniadi, S., Ifie, I., Ho, P. and Murray, B.S. (2019). Evaluation of total monomeric anthocyanin, total phenolic content and individual anthocyanins of foam-mat freeze-dried and spray-dried blueberry powder. Food Measurement and Characterization,
13(1), 1599-1606. https://doi.org/10.1007/s11694019-00076-w

Dregus, M. and Engel, K.H. (2003). Volatile Constituents of Uncooked Rhubarb (Rheum rhabarbarum L.) Stalks. Journal of Agricultural and Food Chemistry, 51(22), 6530-6536. https:// doi.org/10.1021/jf0303991

Faridah, D.N., Yasni, S., Suswantinah, A. and Aryani, G.W. (2013). Shelf Life Estimation by Accelerated Shelf-Testing Method for the Product of Instant Bandrek and Nutmeg Syrup (Myristica fragrans). Jurnal Ilmu Pertanian Indonesia, 18(3), 144-153.

Ferreira, V., Aznar, M., López, R. and Cacho, J. (2001). Quantitative Gas Chromatography-Olfactometry Carried out at Different Dilutions of an Extract. Key Differences in the Odor Profiles of Four HighQuality Spanish Aged Red Wines. Journal of Agricultural and Food Chemistry, 49(10), 48184824. https://doi.org/10.1021/jf010283u

Gorinstein, S., Poovarodom, S., Leontowicz, H., Leontowicz, M., Namiesnik, J., Vearasilp, S., Haruenkit, R., Ruamsuke, P., Katrich, E. and Tashma, Z. (2011). Antioxidant properties and bioactive constituents of some rare exotic Thai fruits and comparison with conventional fruits. In vitro and in vivo studies. Food Research International, 44(7), 2222-2232.

https://doi.org/10.1016/ j.foodres.2010.10.009

Ho, L.H. and Bhat, R. (2015). Exploring the potential nutraceutical values of durian (Durio zibethinus L.) An exotic tropical fruit. Food Chemistry, 168, 8089. https://doi.org/10.1016/j.foodchem.2014.07.020

Krokida, M.K. and Philippopoulos, C. (2006). Volatility of apples during air and freeze drying. Journal of Food Engineering, 73(2), 135-141. https:// doi.org/10.1016/j.jfoodeng.2005.01.012

Lee, S.-J. and Noble, A.C. (2003). Characterization of Odor-Active Compounds in Californian Chardonnay Wines Using GC-Olfactometry and GC-Mass Spectrometry. Journal of Agricultural and Food Chemistry, 51(27), 8036-8044. https:// doi.org/10.1021/jf034747v

Miranda-Lopez, R., Libbey, L.M., Watson, B.T. and McDaniel, M.R. (1992). Odor Analysis of Pinot Noir Wines from Grapes of Different Maturities by a Gas Chromatography-Olfactometry Technique (Osme). Journal of Food Science, 57(4), 985-993. https:// doi.org/10.1111/j.1365-2621.1992.tb14339.x

Peterson, D.G. and Reineccius, G.A. (2003). Characterization of the volatile compounds that constitute fresh sweet cream butter aroma. Flavour and Fragrance Journal, 18(3), 215-220. https:// 
doi.org/10.1002/ffj.1192

Ratti, C. (2013). Freeze drying for food powder production In Bhandari, B., Bansal, N., Zhang, M. and Schuck, P. (Eds). Handbook of Food Powders, p. 57-84. Cambridge, United Kingdom: Woodhead Publishing Limited. https:// doi.org/10.1533/9780857098672.1.57

Schieberle, P. and Grosch, W. (1987). Evaluation of the flavour of wheat and rye bread crusts by aroma extract dilution analysis. Zeitschrift Für Lebensmittel -Untersuchung Und Forschung, 185(2), 111-113. https://doi.org/10.1007/BF01850088

Schieberle, P. and Grosch, W. (1988). Identification of potent flavor compounds formed in an aqueous lemon oil/citric acid emulsion. Journal of Agricultural and Food Chemistry, 36(4), 797-800. https://doi.org/10.1021/jf00082a031

Selli, S., Rannou, C., Prost, C., Robin, J. and Serot, T. (2006). Characterization of aroma-active compounds in rainbow trout (Oncorhynchus mykiss) eliciting an off-odor. Journal of Agricultural and Food Chemistry, 54(25), 9496-9502. https:// doi.org/10.1021/jf0619582

Setyadjit, S., Sukasih, E. and Arif, A.B. (2017). Prediction of Storage Life of Shallot Powder by using Acceleration Method. International Journal of Agriculture System, 5(2), 140-153. https:// doi.org/10.20956/ijas.v5i2.1236

Takahashi, M. and Shibamoto, T. (2008). Chemical Compositions and Antioxidant/Anti-inflammatory Activities of Steam Distillate from Freeze-Dried Onion (Allium cepa L.) Sprout. Journal of Agricultural and Food Chemistry, 56(22), 1046210467. https://doi.org/10.1021/jf801220b

Umano, K. and Shibamoto, T. (1987). Analysis of headspace volatiles from overheated beef fat. Journal of Agricultural and Food Chemistry, 35(1), 14-18. https://doi.org/10.1021/jf00073a004

Voon, Y.Y., Sheikh Abdul Hamid, N., Rusul, G., Osman, A. and Quek, S.Y. (2007). Volatile flavour compounds and sensory properties of minimally processed durian (Durio zibethinus cv. D24) fruit during storage at $4^{\circ} \mathrm{C}$. Postharvest Biology and Technology, 46(1), 76-85. https://doi.org/10.1016/ j.postharvbio.2007.04.004

Voon, Y.Y., Sheikh Abdul Hamid, N., Rusul, G., Osman, A. and Quek, S.Y. (2007). Volatile flavour compounds and sensory properties of minimally processed durian (Durio zibethinus cv. D24) fruit during storage at $4^{\circ} \mathrm{C}$. Postharvest Biology and Technology, 46(1), 76-85.

Weenen, H., Koolhaas, W.E. and Apriyantono, A.
(1996). Sulfur-Containing Volatiles of Durian Fruits (Durio zibethinus Murr.). Journal of Agricultural and Food Chemistry, 44(10), 3291-3293. https:// doi.org/10.1021/jf960191i

Zhang, Z., Zeng, D. and Li, G. (2007). The study of the aroma profile characteristics of durian pulp during storage by the combination sampling method coupled with GC-MS. Flavour and Fragrance Journal, 22(1), 71-77. https://doi.org/10.1002/ ffj.1761 